INTERNATIONAL JOURNAL FOR

HISTORY, CULTURE AND MODERNITY

www.history-culture-modernity.org

Published by: Uopen Journals

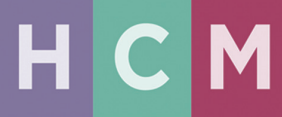

Copyright: @ The Author(s).

Content is licensed under a Creative Commons Attribution 4.0 International Licence

elSSN: 2213-0624

\title{
Introduction: The Material Culture of Politics
}

Jan Hansen, Jochen Hung, Andrew Tompkins, Phillip Wagner

HCM 6 (x): 1-12

DOI: $10.18352 / \mathrm{hcm} .537$

Keywords: Cold War, consumption, human rights, material culture, political history

From furniture to appliances and technology, historians of contemporary Europe have developed a new sensibility for the material world in recent years. They have provided us with fascinating insights into how mundane items such as sofas, tables and kitchens came to represent rival political aspirations in the emerging 'mass consumer societies' after I945. ${ }^{1}$ The articles collected in this special issue take up the threads of these works and delve deeper into the connections between politics and things in post-I945 Europe.

By exploring the materiality of politics, we hope to expand on methodological developments in the field of political history. Particularly in Western Europe and North America, political history has undergone radical change in the last forty years. Since the cultural and linguistic turns of the late I970s and early I980s, scholars have increasingly turned away from solely focusing on monarchs, statesmen, party leaders and parliaments as objects of political history. A revised political history now includes social movements on the local and transnational levels as well as marginalized groups and intellectuals in order to explain the dynamics of politics. Starting with a reinterpretation of the French Revolution, political history discovered new topics such as the symbolism, language, performance and culture of politics. ${ }^{2}$ Against the backdrop of these debates, this special issue holds that the 'political' results from communication that aims to define and transform social rules in a broad sense. ${ }^{3}$ The authors do not conceive of the 'political' 
and the 'non-political' as fixed entities but rather as amorphous categories constantly being reconfigured by communication.

More recently, the so-called material turn has likewise sparked discussion about the methodologies of political history. Historians as well as scholars from neighbouring disciplines such as anthropology and sociology began focusing on the past's materiality as early as in the I 980 os and I990s. While the material turn can be roughly defined as the study of material culture concerned with the relationship between human beings and physical artefacts, scholarship in this field continues to develop and diversify. ${ }^{4}$ As an interdisciplinary approach, the material turn has forced scholars to take seriously what Arjun Appadurai calls the 'social life of things'. ${ }^{5}$ Since the objects under investigation are commonly understood not as 'natural', but created by human beings, they carry cultural significance, inform social relations and structure individual or collective identities. ${ }^{6}$ Judy Attfields defines them as "wild things', whose meanings change constantly. ${ }^{7}$ Material objects have their own stories and their own biographies; they are historical and contingent products. From the perspective of the material turn, however, the encounter between human beings and material artefacts is central to the production of social meaning in the human sphere. ${ }^{8}$

Focusing the spotlight on the materiality of the past prompts historians both to reinterpret existing documentation and to broaden their source base. The contributions here, for instance, work with visual, audiovisual and material sources while also drawing on more traditional written documents. To varying degrees, they also grapple with the question of the historical agency of things, which is still one of the most controversial issues of material culture studies. Even if the implications of Bruno Latour's work on actor-network theory remain contested among historians, the contributors demonstrate that materiality was crucial for the making of the social. ${ }^{9}$ Put another way, '[t]hings here matter, but not to the exclusion of human agency'. ${ }^{10}$ By adding a material culture approach to the analysis of the political, the contributions here clearly showcase the importance of the former to the latter. Taken together, they demonstrate how materiality was constitutive of the notion of the political.

This special issue thus connects with ongoing efforts to include material culture in the study of political history. In recent years, scholars have criticized political history for its preoccupation with seemingly rational political discourse. Political communication relates not 
only to human actors, language and abstractions but also to physical objects, spaces and bodies; it involves the use of political technologies (for instance campaign vans), architecture (e.g. parliament buildings) and the deployment of consumer goods (such as kitchen appliances). Inspired by the material turn in science and technology studies, anthropology and cultural studies, scholars have taken a new look at the political history of things. Whereas some have charted the way in which commodities contributed to the construction of power relations at both national and transnational levels, others, steeped in Foucauldian terminology, have focused on the material side of administration and government, analysing how work environments and paperwork created rules, institutions and knowledge. ${ }^{11}$ In the context of this research, Frank Trentmann has advanced the study of 'material politics' by systematically including the 'thingness of politics' and the 'politicization of things'.$^{12}$ Informed by this perspective, we do not conceive of objects and things as neutral carriers for political arguments. Rather, we hold that the material transgresses procedures, spaces and rules of political communication and serves as a medium for political expression, representation and contestation.

This transgressive potential of the material is perhaps most apparent in spaces and contexts where words and arguments are supposed to prevail, such as parliament. In their article analysing the material culture of the Dutch parliament, Carla Hoetink and Harm Kaal argue that architecture, objects and performances contribute to, but also defy, politicization. While the current parliamentary building aims to communicate transparency and participation through the open space of its entry hall, security concerns have now actually closed it. The plenary hall itself is austere in its symbolism - until late 2017, it did not even contain a national flag. This was in keeping with Dutch parliamentarians' understanding of their institution as one of rational debate and argumentative persuasion. A space whose material characteristics remain dominated by paper and the clock, it has nevertheless been transformed by the presence of cameras and microphones. Playing to this outside audience, some MPs have drawn on material props to grandstand or make emotional - often populist - appeals. In such a space, the presence of outside objects can be in and of itself a form of disruption.

This and the other case studies analysed here - from Anti-Apartheid stickers to East German do-it-yourself (DIY) culture - are all located in 
post-I945 Europe. The period after the Second World War was characterized by transformational processes in politics and wider culture. On a broader scale, European Cold War culture was shaped by the existence of two competing and highly politicized models of modernity. Things (and the practices related to them) became prominent signifiers for these models and they were marshalled - implicitly or explicitly - for support: the Soviet National Exhibition in New York and the American National Exhibition in Moscow in 1959 (where the famous 'kitchen debate' between Nixon and Khrushchev took place) are only two of the best-known examples of how mundane objects were used to show the supposed superiority of each political order. ${ }^{13}$ Another illustration of this systemic competition was the manner in which East Germany attempted to politicize the domain of housing by asking citizens to 'join in' and beautify their homes and communities. As Reinhild Kreis demonstrates, this was not 'do-it-yourself' in the same sense as in West Germany (where public beautification projects were likewise promoted), but a distinctly socialist form of mobilizing that mixed public and private. The East German state set up a small infrastructure to support such projects, permitting rationalization of (and control over) the allocation and distribution of tools that might otherwise be difficult to come by. In effect, part of the state's housing plan could thereby be outsourced to private citizens. However, participants were likely motivated more by opportunities to access such resources for private, individual ends than by the ideological commitment that the Party would have liked. Cold War competition thus politicized everyday 'DIY' activities, if not necessarily in the ways that authorities intended.

This politicization was part and parcel of arguably the most significant transformation of post-war Europe: the development of a stable 'mass consumer society'. The rise in living standards and purchasing power meant that consumer products and practices became both more ubiquitous and more important: as European homes filled up with washing machines, fridges and telephones, these things acquired increased significance as, in Bourdieu's words, 'the ideal weapon in strategies of [social] distinction'. ${ }^{14}$ On both sides of the 'Iron Curtain', this transformation raised questions about consumption's impact on the political organization of society: could consumer society be squared with democracy or even with socialism? The answers varied: in the 
Eastern Bloc, the reaction to the development of consumer society oscillated between official rejection and competition with the Western model. ${ }^{15}$ In the West, politicians like Ludwig Erhard, the 'father' of the West German 'economic miracle', saw consumer society as intricately intertwined with Western liberal democracy. ${ }^{16}$ Others, like Jürgen Habermas, criticized this development as 'depoliticization' of public life. ${ }^{17}$ For Habermas and other observers, this was closely intertwined with the change of the post-war media landscape, most importantly the explosive spread of television after I945. The TV set became the symbol and the prime agent of the fully developed consumer society, acting as the central channel through which this lifestyle was promoted. ${ }^{18}$ Easily consumable TV formats such as talk shows and infotainment magazines seemed to trivialize and undermine political culture and democratic discourse. ${ }^{19}$ However, historians have shown that consumption did not lead to depoliticization, but in fact became part of the political. Scholars like Lizabeth Cohen, Victoria de Grazia, Sheryl Kroen, Matthew Hilton and Claudius Torp have described how closely related politics and consumption became after $1945 .{ }^{20}$

According to Frank Trentmann, the best category for jointly analysing consumption, things and politics is 'the everyday' ${ }^{21}$ The intersection of these in the 'everyday' was particularly apparent in the so-called 'New Social Movements' that emerged in the I970s, which included feminism, environmentalism and human rights. ${ }^{22}$ The latter developed, in close connection with decolonization and the dissolution of European empires, 'into a political and legal vocabulary for confronting abuses of disciplinary state power' ${ }^{23}$ In Europe itself, human rights discourse fed into a new, more individualized style of politics outside of traditional structures: according to Michel Foucault, organizations such as Amnesty International or Terre des Hommes expressed a new belief in 'the right of private individuals to intervene actively and materially in the order of international politics and strategy. ${ }^{24}$ These organizations and the discourses they expounded insinuated themselves into everyday life in part through the presence of objects: stickers and buttons, but also ordinary goods selected for conscious consumption (or active non-consumption). Benjamin Möckel's essay focuses on boycotts of South African goods (whose origins were often disguised) and the monitoring that British and other anti-Apartheid activists engaged in as part of their political commitment. In this sense, it was social 
practices that embedded material objects - and the political meanings they might convey - into everyday life. Activists inspected countryof-origin labels and even attempted to discern by an orange's skin if it was 'contaminated' with Apartheid. Sometimes, activists offered to replace consumers' purchases with 'clean' alternatives from Frontline States such as Zimbabwe that challenged Apartheid. At other times, they turned boycotts into 'buycotts', selling posters and coffee mugs depicting Nelson Mandela in order to raise funds for their cause. These actions had the potential to take humanitarian feelings of 'guilt' over the complicity of one's own government with racism half a world away and channel it into action. Refusing to buy a product was a means of exercising agency over distant evildoers, but also of pulling a distant political struggle into one's own everyday life.

Post-war modernity quickly set new norms of consumption, leading to the integration of new appliances and commodities into everyday life that generated their own practices and habits as well as 'expectations that could exert pressure on public life and politics' ${ }^{25}$ Access to these products came to be seen as a civil right, which could be demanded from the public authorities, and which led to closer relationships between end users, for instance in the form of consumer associations or fair trade organizations. Those relationships could reach across borders and even across the 'Iron Curtain' as well, prompting individual intervention where authorities failed to fulfil perceived human needs. Cristian Capotescu examines precisely such a non-institutional form of humanitarianism connected with consumption: private gifts from Germans to Romanians during the Cold War. Such gift-giving was spurred on in part by kinship ties with ethnic Germans from Romania, who had migrated to West Germany during or after the Second World War. According to Capotescu, these Germans saw solidarity as a moral duty rather than a political act. The Romanian state thus tolerated even large-scale imports intended for donors' relatives, interpreting them in relation to tourism rather than smuggling. East Germans as well acted on the basis of a moral impulse, expressing a solidarity that was born of a twin sense of 'radical equality' among Soviet-aligned planned economies and their own relative wealth within the bloc. Humanitarian action, both organized and individual, soared after the floods of 1970 and I975, but private giving continued well after the disaster relief mandates of official organizations had expired. It thus served as critical 
assistance during the period of drastic austerity imposed by Romanian authorities in the I980s.

From the perspective of post-I945 European history, these essays pose the question of how material objects and the practices associated with them relate to the category of the 'political', especially compared to the words and discourses that have tended to dominate 'politics'. Taken together, these articles demonstrate various ways in which objects became intrinsic to political communication in the societies of Cold War Europe. Consumer items became essential features in expressing, defending and challenging political meaning. By expanding the rules of political communication, things - and their associated practices - also contributed to altering the structure of political discourse. Objects are subject to the agency of those that would use them, but they can also obstinately resist any definitive meaning that their users might seek to impose. Attention to materiality thus reminds us of the work - practices, processes and performances - involved in imbuing the world with meaning. At the same time, things physically and symbolically structure political acts in ways that impede completely open-ended interpretations: objects themselves can generate unexpected (and unintended) dynamics. Material culture then forms a necessary part of political history, possessing the potential to disrupt the apparent certainties of "politics'. When we interpret the political solely in terms of seemingly clear discursive abstractions, we risk losing sight of the material rough edges that make it so contested, conflicting and problematic.

\section{Acknowledgements}

We would like to thank the editorial board of the International Journal of History, Culture and Modernity and its anonymous reviewers for their support and helpful suggestions. This special issue represents a selection of revised contributions to a conference that was held at HumboldtUniversität zu Berlin (HU) in March 20I6. The editors would like to thank the HU Berlin and its KOSMOS program for crucial financial support. We would also like to thank Benjamin Ziemann (University of Sheffield), who gave the keynote of this conference. The editors are grateful to Gabriele Metzler (HU Berlin), Jan Logemann (GeorgAugust-Universität Göttingen), Stefan Couperus (Rijksuniversiteit 
Groningen) and Claudia Gatzka (Albert-Ludwigs-Universität Freiburg) for serving as commentators at the conference.

\section{About the Authors}

Jan Hansen is Assistant Professor (Wissenschaftlicher Mitarbeiter) of History at the Humboldt-Universität zu Berlin and a Fellow in the History of the Americas at the German Historical Institute in Washington, D.C. His research interests lay at the intersection of the anthropology of infrastructure, environmental history, and urban history. His previous work includes research on the cultural and social history of the Cold War, with a special emphasis on anti-nuclear protests. He is the author of 'Shaping the Modern Body: Water Infrastructure in Los Angeles (I870-I920)', Body Politics 6:9 (2018), 47-70 and Abschied vom Kalten Krieg? Die Sozialdemokraten und der Nachrüstungsstreit (1977-1987) (Berlin, 2016).

Jochen Hung is Assistant Professor (Universitair Docent) of Cultural History at Utrecht University. His research focuses on the relationship between media, culture and society in modern history. He has published on gender representations in interwar culture, German-Jewish publishing and national identity, and youth culture in the Weimar Republic. His forthcoming book A Moderate Modernity. The Newspaper Tempo and the Collapse of the Weimar Republic, 1928-1933, published by University of Michigan Press, covers the changes of German media discourses on gender, consumption, and democracy during the rise of the Nazis.

Andrew Tompkins is Lecturer in Modern History at the University of Sheffield. His first monograph, Better Active than Radioactive! AntiNuclear Protest in 1970s France and West Germany, was published with Oxford University Press in 20I6. It focuses on how French and West German activists engaged with one another across national, political, and social boundaries within the anti-nuclear movement. His current research project examines the Rhine and Oder-Neisse borderlands as spaces of interaction between French, German, and Polish citizens after 1945 . 
Phillip Wagner is Assistant Professor (Wissenschaftlicher Mitarbeiter) at Martin-Luther Universität Halle-Wittenberg. He has published on citizenship and education in West Germany, expert internationalism, and urban history, including 'Between National Socialism and Expert Internationalism: Karl Strölin and Transnationalism in Urban Planning, I938-45', European Review of History 25:4 (2018), forthcoming; 'Das Mitbürgerliche und das Staatsbürgerliche: Politische Bildung, Bürgerlichkeit und Demokratie im Westdeutschland der I940er und I950er Jahre', in Manfred Hettling and Richard Pohle (eds.), Bürgertum: alte Fragen und neue Perspektiven (Göttingen, 20I 8), forthcoming; Stadtplanung für die Welt? Internationales Expertenwissen 1900-1960 (Göttingen, 20I6).

\section{Notes}

I See Greg Castillo, Cold War on the Home Front: The Soft Power of Midcentury Design (Minneapolis, 20I0); Ruth Oldenziel and Karin Zachmann, 'Kitchens as Technology and Politics: An Introduction', in Ruth Oldenziel and Karin Zachmann (eds), Cold War Kitchen: Americanization, Technology, and European Users (Cambridge, MA, 2009) I-29; Paul Betts, The Authority of Everyday Objects: A Cultural History of West German Industrial Design (Berkeley, 2007).

2 Lynn Hunt, Politics, Culture, and Class in the French Revolution (Berkeley, I984).

3 Good starting points for the debate in the United States, Britain, France and Germany are 'Focus: Political History Today', Perspectives on History 49:5 (20 I I); David M. Craig, "High Politics" and the "New Political History", The Historical Journal 52:2 (2010) 453-475; Pierre Rosanvallon, Pour une histoire conceptuelle du politique (Paris, 2003); Thomas Mergel, 'Überlegungen zu einer Kulturgeschichte der Politik', Geschichte und Gesellschaft 28:4 (2002) 574-606; Willibald Steinmetz and Heinz-Gerhard Haupt, 'The Political as Communicative Space in History: The Bielefeld Approach', in Willibald Steinmetz et al (eds), Writing Political History Today (Frankfurt am Main 20I3) 2I-3I; and 'Forum: The Contours of the Political', German History 33:2 (2015) 255-273.

4 Christopher Tilley et al (eds), Handbook of Material Culture (London, 2006); see also Simone Derix et al, 'Der Wert der Dinge. Zur Wirtschafts- und 
Sozialgeschichte der Materialitäten', Zeithistorische Forschungen/Studies in Contemporary History I 3:3 (2016) 387-403.

5 Arjun Appadurai, 'Introduction: Commodities and the Politics of Value', in Arjun Appadurai (ed.), The Social Life of Things: Commodities in Cultural Perspective (Cambridge, I986) 5.

6 Leora Auslander, 'Beyond Words', American Historical Review i Io:4 (2005) IOI 5-I045.

7 Judith Attfield, Wild Things: The Material Culture of Everyday Life (Oxford, 2000).

8 Anke Ortlepp and Christoph Ribbat (eds), Mit den Dingen leben. Zur Geschichte der Alltagsgegenstände (Stuttgart, 2010).

9 Bruno Latour, Reassembling the Social: An Introduction to Actor-NetworkTheory (Oxford, 2005).

Io Frank Trentmann, 'Political History Matters: Everyday Life, Things and Practices', in Steinmetz et al (eds), Writing Political History Today, 397408: 407.

I I For remarkable examples of both strands of research, see Sven Beckert, Empire of Cotton: A Global History (New York, 20I4); Patrick Joyce, The State of Freedom: A Social History of the British State since 1800 (Cambridge, 2013); and the methodological discussion in Patrick Joyce, 'What is the Social in Social History', Past and Present 206 (2010) 2 I3-248.

I 2 Frank Trentmann, 'Materiality in the Future of History: Things, Practices, and Politics', Journal of British Studies 48:2 (2009) 299; Trentmann, 'Political History Matters', 408.

I3 Susan E. Reid, 'Cold War in the Kitchen: Gender and the De-Stalinization of Consumer Taste in the Soviet Union under Khrushchev', Slavic Review 6I:2 (2002) 2 I I-252; Oldenziel and Zachmann, 'Kitchens as Technology and Politics'. For a recent overview examining Cold War Europe, see Konrad H. Jarausch, Out Of Ashes: A New History of Europe in the Twentieth Century (Princeton, 2015) 399-693.

I4 Pierre Bourdieu, Distinction: A Social Critique of the Judgement of Taste (London, 2010) 59.

I5 Ina Merkel, 'From Stigma to Cult: Changing Meanings in East German Consumer Culture', in Frank Trentmann (ed.), The Making of the Consumer: Knowledge, Power and Identity in the Modern World (Oxford, 2006) 249-270; Philipp Heldmann, 'Negotiating Consumption in a Dictatorship: Consumption Politics in the GDR in the I950s and I960s', in 
Martin Daunton and Matthew Hilton (eds), The Politics of Consumption: Material Culture and Citizenship in Europe and America (Oxford, 200I) I 85-202.

I6 Michael Wildt, “Wohlstand für alle”: Das Spannungsfeld von Konsum und Politik in der Bundesrepublik', in Heinz-Gerhard Haupt and Claudius Torp (eds), Die Konsumgesellschaft in Deutschland 1890-1990. Ein Handbuch (Frankfurt, 2009) 3 I 4.

I7 See, for example, Jürgen Habermas, Legitimation Crisis (Boston, I975); The Structural Transformation of the Public Sphere. An Inquiry into a Category of Bourgeois Society (Cambridge, I989).

I8 Jochen Hung, 'Consumers / Consumption', in Adrian Bingham (ed.), A Cultural History of the Media in the Modern Age (Hoboken, forthcoming).

I9 Peter Dahlgren, Television and the Public Sphere: Citizenship, Democracy and the Media (London, I995) 46-70.

20 Lizabeth Cohen, A Consumer's Republic: The Politics of Mass Consumption in Postwar America (New York, 2003); Victoria de Grazia, Irresistible Empire: America's Advance through Twentieth-Century Europe (Cambridge, 2005); Sheryl Kroen, 'Negotiations with the American Way: The Consumer and the Social Contract in Postwar Europe', in John Brewer and Frank Trentmann (eds), Consuming Cultures, Global Perspectives: Historical Trajectories, Transnational Exchanges (London, 2006) 25I277; Matthew Hilton, Prosperity for All: Consumer Activism in an Era of Globalization (Ithaca, 2009); Claudius Torp, Wachstum, Sicherheit, Moral. Politische Legitimationen des Konsums im 20. Jahrhundert (Göttingen, 20I2). For an excellent overview of recent research on the topic, see Peter Van Dam, 'Tales of the Market: New Perspectives on Consumer Society in the 2oth Century', H-Soz-Kult, www.hsozkult.de/literaturereview/id/ forschungsberichte-2832, accessed I March 2018.

2 I Frank Trentmann, 'The Politics of Everyday Life', in Frank Trentmann (ed.), The Oxford Handbook of the History of Consumption (Oxford, 20I 2) $52 \mathrm{I}-547$.

22 See Claus Offe, 'New Social Movements: Challenging the Boundaries of Institutional Politics', Social Research 52:4 (I985) 8I7-868; Nelson Pichardo, 'New Social Movements: A Critical Review', Annual Review of Sociology 23 (I997) 4I I-430.

23 Stefan-Ludwig Hoffmann, 'Introduction: Genealogies of Human Rights', in Stefan-Ludwig Hoffmann (ed.), Human Rights in the Twentieth Century (Cambridge, 20IO) 2; Roland Burke, Decolonization and the Evolution of 
HANSEN ET AL.

International Human Rights (Philadelphia, 20Io); Jan Eckel and Samuel Moyn (eds), The Breakthrough: Human Rights in the 1970s (Philadelphia, 20I2).

24 Michel Foucault, 'Face aux gouvernements, les droits de l'homme [I984]', in Dits et écrits, vol. 4: 1980-1988 (Paris, 1994) 707-708. Translation by Colin Gordon on OpenDemocracy, www.opendemocracy.net/can-europemake-it/michel-foucault/rights-and-duties-of-international-citizenship, accessed I March 2018.

25 Trentmann, 'The Politics of Everyday Life', 543. 